\title{
Dorsal Parietal Area 5 Encodes Immediate Reach in Sequential Arm Movements
}

\author{
Yuhui Li (李宇辉) ${ }^{1}$ and He Cui (崔翯) $)^{1,2}$ \\ ${ }^{1}$ Brain and Behavior Discovery Institute, and ${ }^{2}$ Department of Psychiatry and Health Behavior, Medical College of Georgia, Georgia Regents University, \\ Augusta, Georgia 30912
}

To generate a coherent action sequence, it is essential to integrate all component movements beforehand, and such sequence-related information has been observed in numerous brain regions. However, this high-level sequential plan encompassing multiple motor elements in parallel ultimately must be decomposed into serial motor commands to be executed by the musculoskeletal system. In the present study, we recorded single-neuron activity from dorsal parietal area 5 (area $5 \mathrm{~d}$ ) while monkeys performed a double-reach task, and found that area $5 \mathrm{~d}$ conveys the immediate upcoming reach, but not the subsequent movement, as opposed to the entire movement sequence being encoded as in other cortical sensorimotor areas. The elementary movement coded in area $5 \mathrm{~d}$ suggests that unfolding of the motor sequence begins in the parietal-frontal cortex, instead of being exclusively implemented by downstream subcortical and spinal circuits.

\section{Introduction}

Our successful interaction with complex environments largely relies on the ability to perform temporally coordinated concatenations of multiple elementary movements. The neural basis of sequential behaviors has been extensively studied (Tanji, 2001; Keele et al., 2003), and information related to serial actions has been revealed in numerous cortical (Ohbayashi et al., 2003; Averbeck et al., 2006; Histed and Miller, 2006; Shima et al., 2007) and subcortical (Hikosaka et al., 1999; Ivry and Spencer, 2004) brain regions. Apparently, distinct areas are involved in different stages and aspects of assembling simple actions into richer repertoires of complex behaviors (Mushiake et al., 1991; Tanji and Shima, 1994; Fujii and Graybiel, 2003).

To produce a coherent action sequence without interruption, it is efficient to first integrate information regarding all component movements and form a high-level plan that simultaneously encodes multiple motor elements (Massey et al., 1986; Cisek and Kalaska, 2010; Baldauf, 2011). However, sequenced actions represented in parallel must ultimately be decomposed into serial motor commands to drive the musculoskeletal system. It remains unclear where and how the chunked motor sequence is unfolded into its serial motor elements.

Most sensorimotor areas have been found to convey information beyond the immediate next movement during sequential planning.

\footnotetext{
Received March 15, 2013; revised July 23, 2013; accepted Aug. 1, 2013.

Author contributions: Y.L. and H.C. designed research; Y.L. and H.C. performed research; Y.L. analyzed data; Y.L. and H.C. wrote the paper.

This work was supported by University System of Georgia Board of Regents, the Whitehall Foundation, and Alfred P. Sloan Research Fellowship to H.C. We thank L. Suppa and E. Tsien for assistance during animal training; R. Andersen, D. Baldauf, D. Blake, J. Malpeli, A. Saul, Z. Yang, and the anonymous reviewers for helpful comments on the manuscript; N. Rodriguez, J. Spurlock, M. Williams-Fritze, Sunday Cozzi, and P. Charlton for veterinary assistance; A. Gambill, T. Goodly, and L. Jarrett for administrative support.

Correspondence should be addressed to He Cui, Brain and Behavior Discovery Institute, Georgia Regents University, Augusta, GA 30912. E-mail: hcui@gru.edu.

DOI:10.1523/JNEUROSCI.1162-13.2013

Copyright $\odot 2013$ the authors $\quad 0270-6474 / 13 / 3314455-11 \$ 15.00 / 0$
}

Even in the primary motor cortex (M1) with direct projections to the spinal motor apparatus (He et al., 1993; Wise et al., 1997; Rathelot and Strick, 2006), many neurons have been found to strongly reflect sensory inputs (Carpenter et al., 1999; Hatsopoulos and Suminski, 2011) and serial motor outputs (Kettner et al., 1996a,b; Lu and Ashe, 2005), in contrast to the traditional view of these cells as "upper motor neurons." In the parietal cortex, the parietal reach region (PRR) has also been found to encompass both goals in the preparatory period during double-reach movements (Baldauf et al., 2008). Together, converging evidence suggests that the cortical sensorimotor circuits might work as a dynamical machine (Churchland et al., 2010) to initiate a whole motor sequence, whereas unfolding might be implemented by descending corticosubcortical and corticospinal circuits.

Here we recorded single-neuron activity from another area in the posterior parietal cortex, dorsal area 5 (area $5 \mathrm{~d}$ ), which is located caudal to the primary somatosensory cortex and medial to the intraparietal sulcus (IPS). Although both the PRR and area $5 \mathrm{~d}$ have been found to be involved in reach planning, converging evidence obtained from single-cell recording (Cui and Andersen, 2011) and human imaging (Medendorp et al., 2005; Filimon et al., 2009; Heed et al., 2011) indicates that they might play distinct roles in planning and control of reach at different stages of the sensorimotor transformation. Our results show that area $5 \mathrm{~d}$ activity is tightly coupled only to the immediate upcoming movement during double reach, suggesting that it plays a unique role in elementary movement preparation and online control, and indicating that unfolding of the motor sequence involves cortical sensorimotor circuits rather than taking place exclusively at subcortical and spinal levels.

\section{Materials and Methods}

Experimental preparation. Two male rhesus monkeys (Macaca mulatta, $7-10 \mathrm{~kg}$ ) participated. After acclimatization, the animals sat in a primate chair $23 \mathrm{~cm}$ in front of a touch screen (Elo Touchsystems; sampling rate $100 \mathrm{~Hz}$, spatial resolution $<0.1 \mathrm{~mm})$ and an LCD monitor $(383.5 \times$ $308.0 \mathrm{~mm}$, refresh rate $60 \mathrm{~Hz}, 800 \times 600$ ), and were trained to perform 


\section{A Central Fixation}

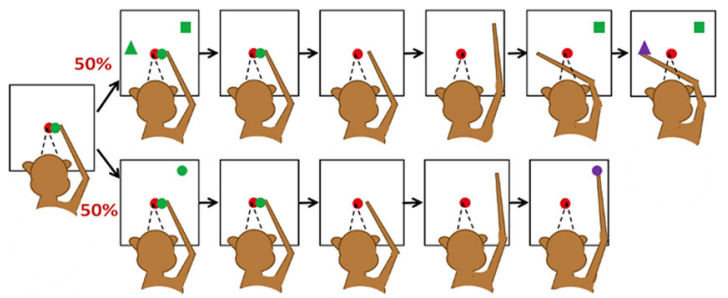

B Free View

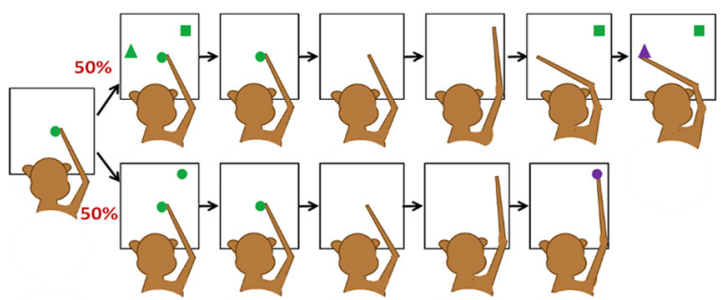

C Reach 2-from-3

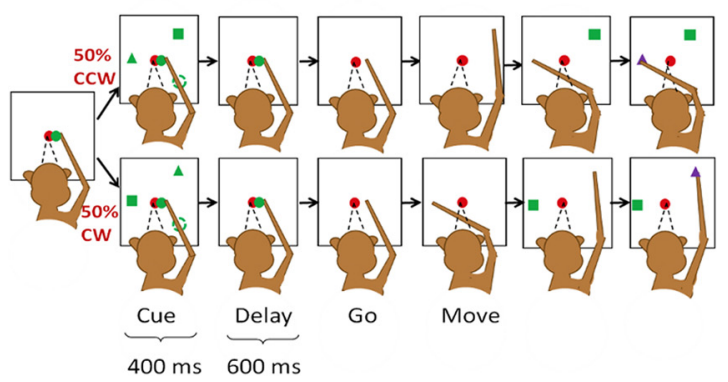

Figure 1. Behavioral tasks. $\boldsymbol{A}$, The main task: interleaved double- (top) and single-reach (bottom) trials in which the monkeys were required to maintain the central fixation throughout each trial. $\boldsymbol{B}$, Free-view condition: monkeys performed the same arm movements as in Figure $1 A$ but were allowed to look anywhere. $C$, Reach 2 -from-3 condition: three targets (a square, a triangle, and a circle) were simultaneously presented at three peripheral locations spaced $120^{\circ}$ apart, and the monkey was trained to reach the square and triangle in correct order. The second target (triangle) could be either $+120^{\circ}$ or $-120^{\circ}$ to the first target (square). The peripheral circle was presented as distracter in a half the trials, but absent in the other half. visually guided single- and double-arm reaching tasks. Near the end of training, a head-post and recording chamber (inside diameter $=19 \mathrm{~mm}$ ) were implanted under anesthesia (premedicated by ketamine $10 \mathrm{mg} / \mathrm{kg}$, induced with $2-3 \%$ isoflurane then maintained by $1 \%$ isoflurane). Eye movements were monitored by an infrared eye-tracker (ISCAN, $120 \mathrm{~Hz}$ ), and the animals were trained to maintain eye-fixation when performing the arm movement tasks. All procedures were in accordance with NIH guidelines and were approved by the Institutional Animal Care and Use Committee of Georgia Regents University.

Behavioral paradigms. At the beginning of the trial, a green circle and a red circle were displayed on the center of the screen, and the monkey was required to touch the green circle and visually fixate the red circle for $300-800 \mathrm{~ms}$. Then, in $50 \%$ of trials (single-reach trials; Fig. $1 \mathrm{~A}$, bottom), the central red and green circles remained on, and a second green circle was presented as a reaching goal for $400 \mathrm{~ms}$ (cue period) at one of eight peripheral locations distributed evenly along the circumference of a circle around the central green circle. After the cue was extinguished, the monkey had to keep his hand on the central green circle for a delay period of $600 \mathrm{~ms}$ before the central green circle was turned off (GO signal), and the monkey was then required to reach to the previously cued location to obtain a reward. In the other $50 \%$ of trials (double-reach trials; Fig. $1 \mathrm{~A}$, top), a green square and a green triangle were displayed simultaneously during the cue period, with the triangle always placed at a location $135^{\circ}$ counter-clockwise from the square. After the $600 \mathrm{~ms}$ delay, the monkey was required to reach the remembered square location first, and then to reach the remembered triangle location. In both the single- and doublereach conditions, the monkey was required to fixate the central red circle, which remained on throughout each trial. Visual feedback was given: the green square reappeared after a successful first touch in double-reach trials, and the circle or the triangle reappeared and turned purple for a successful final touch in single and double reaching trials, respectively. The 16 trial types (eight for single reach and eight for double reach) were pseudo-randomly interleaved.

In the free-view condition (Fig. 1B), monkeys were required to perform tasks with arm movements identical to those of the main tasks illustrated in Figure $1 A$, except that there was no central red circle in the display, and the monkey was allowed to move his eyes freely. All neural data in this free-view condition were collected before any eye movementrelated training.

In the reach 2-from-3 task (Fig. $1 C$ ), a monkey was trained to reach to the square and triangle in the correct order while maintaining central fixation, similar to the behavioral paradigm described in Figure $1 \mathrm{~A}$. However, there were three differences: (1) reach targets appeared at one
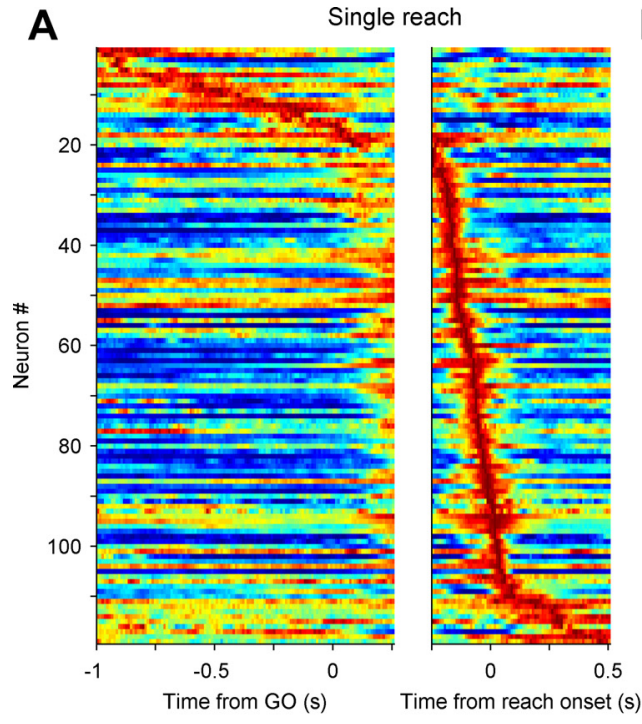

B

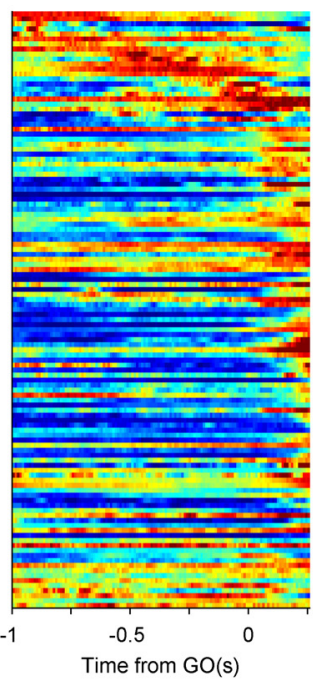

Double reach

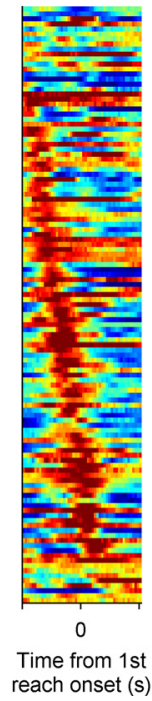

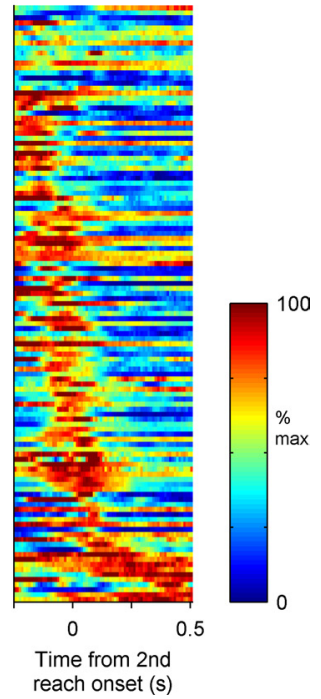

Figure 2. Temporal profile of area $5 \mathrm{~d}$ cells. Each colored line indicates one cell's normalized mean firing rate across all trials in single $(\boldsymbol{A})$ and double $(\boldsymbol{B})$ reaches. The cells are sorted by time of the peak firing rate in single-reach trials, while the activity is aligned to the $G 0$ signal and reach onset in $\boldsymbol{A}$ and the $\mathrm{G} 0$ signal, first reach onset, and second reach onset in $\boldsymbol{B}$. 
Table 1. Numbers of cells showing significant directional tuning for delay, pre movement, and perimovement periods during single- and double-reach trials

\begin{tabular}{llll}
\hline & Delay & Premovement & Perimovement \\
\hline SR & 33 & 87 & 72 \\
1st in DR & 33 & 82 & 82 \\
2nd in DR & - & 78 & 81 \\
SR \& 1st in DR & 16 & 69 & 61 \\
SR \& 2nd in DR & - & 64 & 61 \\
1st \& 2nd in DR & - & 69 & 67 \\
SR, 1st \& 2nd in DR & - & 59 & 58 \\
\hline
\end{tabular}

$S R$, Single reach; DR, double reach.

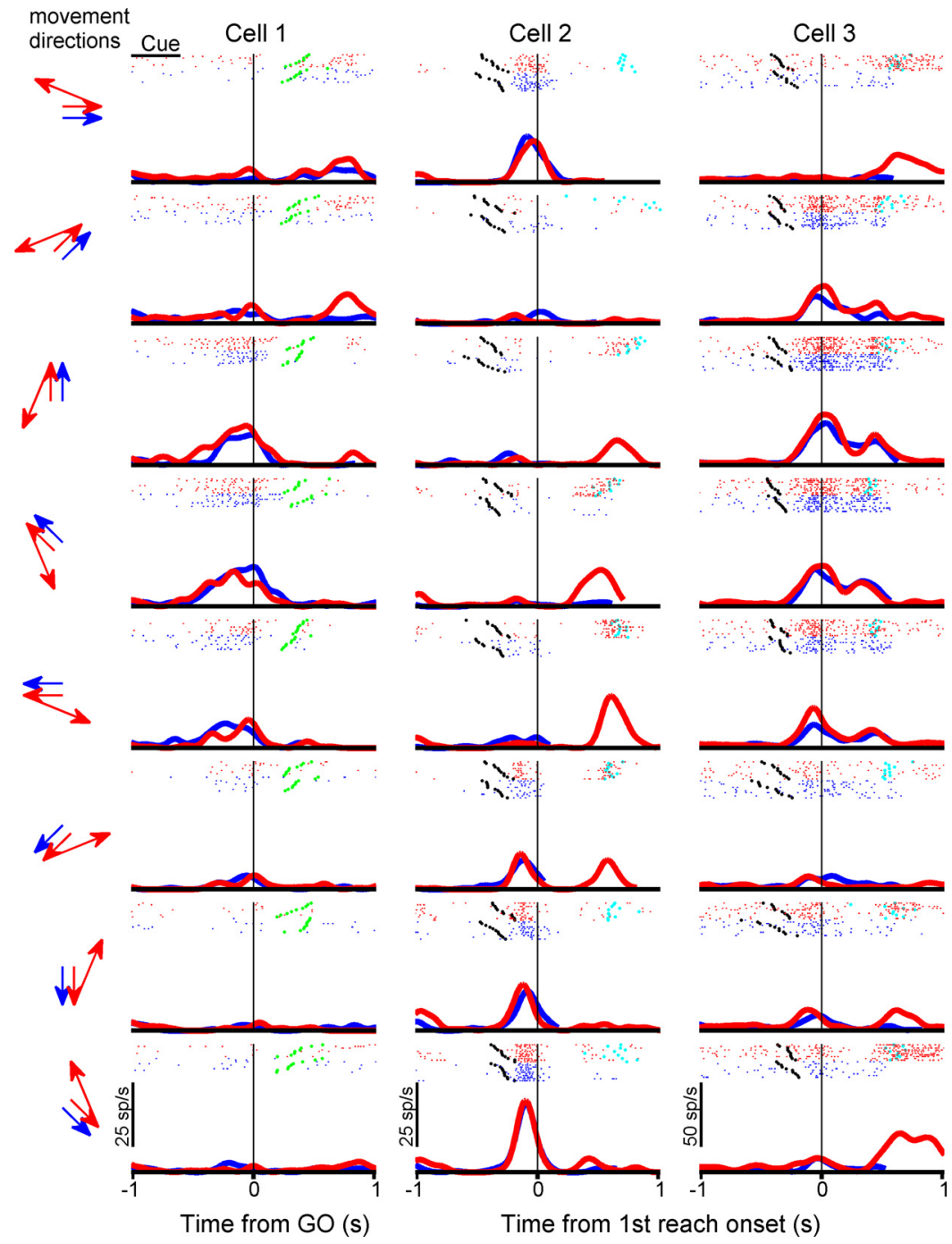

Figure 3. Three typical area $5 \mathrm{~d}$ cells. Blue and red indicate results from single-reach trials and double-reach trials, respectively. Each panel presents activity during one single reach (blue) and one double reach (red) for the reach directions indicated by arrows on the left. Each raster shows spike train in each single- (blue) and double-reach (red) trials. The black, green, and cyan dots mark the GO signal time, the first movement onset, and the second movement onset, respectively. The curves are PSTHs, smoothed using a Gaussian kernel ( $S D=50 \mathrm{~ms})$.

of six locations evenly distributed (every $60^{\circ}$ ) along the circumference; (2) in double-reach trials the second target was pseudo-randomly presented either $120^{\circ}$ clockwise or $120^{\circ}$ counter-clockwise to the first target; (3) in $50 \%$ of trials a third peripheral target (a green circle) appeared $120^{\circ}$ apart from both the first and second reach target, so the three targets were evenly distributed along the circumference. However, the third target was a distracter, and the animal was trained to ignore it while making the double reach. Therefore there were a total of 30 trial conditions: six single-reach conditions and 24 double-reach conditions $[6 \times 2$ (second target location) $\times 2$ (with or without distracter) $]$. Because the response properties were very similar for the conditions with and without a distracter, for simplicity we only present the results for conditions without a distracter.

The diameter of all the targets was $1.0 \mathrm{~cm}$ (corresponding to $\sim 2.5^{\circ}$ in visual angle), and the distance from the central circle to the peripheral target was $8.0 \mathrm{~cm}\left(\sim 20^{\circ}\right.$ in the visual field $)$. After a successful trial, a small amount of liquid food (blended from monkey biscuits, bananas, apple sauce, and water) was delivered after a $500 \mathrm{~ms}$ delay. Aborted trials were pseudo-randomly repeated until success. In a typical day, a monkey performed $\sim 1000$ trials, and 8-12 trials were collected for each condition in each recording session. Visual stimuli were generated by VisionEgg (Straw, 2008). Labview (National Instrument) was used to monitor/ control the animals' behavioral performance. All information about the visual stimuli and eye/hand variables was synchronized with the neuronal recording data, and stored in an integrated manner for post hoc analysis.

Data collection. Glass-coated tungsten electrodes (Alpha-Omega, $\sim 1 \mathrm{M} \Omega$ impedance at 1 $\mathrm{kHz}$ ) were driven by an Alpha-Omega electrode positioning system through a grid matrix attached to the chamber into the gyral surface of the superior parietal lobule (referred to as $\mathrm{PE}$ by Matelli and Luppino, 2001) and recording depths were restricted to within $2 \mathrm{~mm}$ from the first encountered neuronal activity. The recording sites were located between 0 and $3 \mathrm{~mm}$ anterior/medial to the IPS, and between 7 and $11 \mathrm{~mm}$ from the midline, and were verified by postmortem examination of the brain for monkey A. Single-unit recordings were made from area $5 \mathrm{~d}$ while monkeys performed one of the three tasks shown in Figure 1 with their contralateral hands, and electrode placement was confirmed by responses to passive somatic stimulation of the limbs. Extracellular activity was recorded with the AlphaMap system (Alpha-Omega), sampled at $50 \mathrm{kHz}$, bandpassed through a $300-10 \mathrm{k} \mathrm{Hz}$ filter and digitally stored for post hoc analysis. Spikes were extracted and sorted off-line using open source software Wave Clus by Quian Quiroga et al. (2004).

\section{Results}

Figure 2 shows the temporal dynamics of the sample of 119 well isolated neurons (76 from monkey A and 43 from monkey P). Activity of all movement directions in single-reach trials was pooled for each cell, normalized by the peak firing rate, and sorted by the timing of the peak (Fig. 2A). For double-reach trials, the pooled activity was normalized and sorted by the firing rate and time of the peak in the single-reach trials, respectively (Fig. 2B). Of these 119 neurons, 33 (28\%), 87 $(73 \%)$, and $72(61 \%)$ exhibited significant directional tuning (one-way ANOVA, $p<0.05)$ in the delay $(-400-0 \mathrm{~ms}$ before $\mathrm{GO})$, premovement ( $-200-0 \mathrm{~ms}$ before movement onset), or perimovement $(0-200 \mathrm{~ms}$ after movement onset) periods during the single-reach trials, respectively. Note that this classification was not exclusive because some cells showed tuning in multiple periods. The temporal profile and directional tuning 

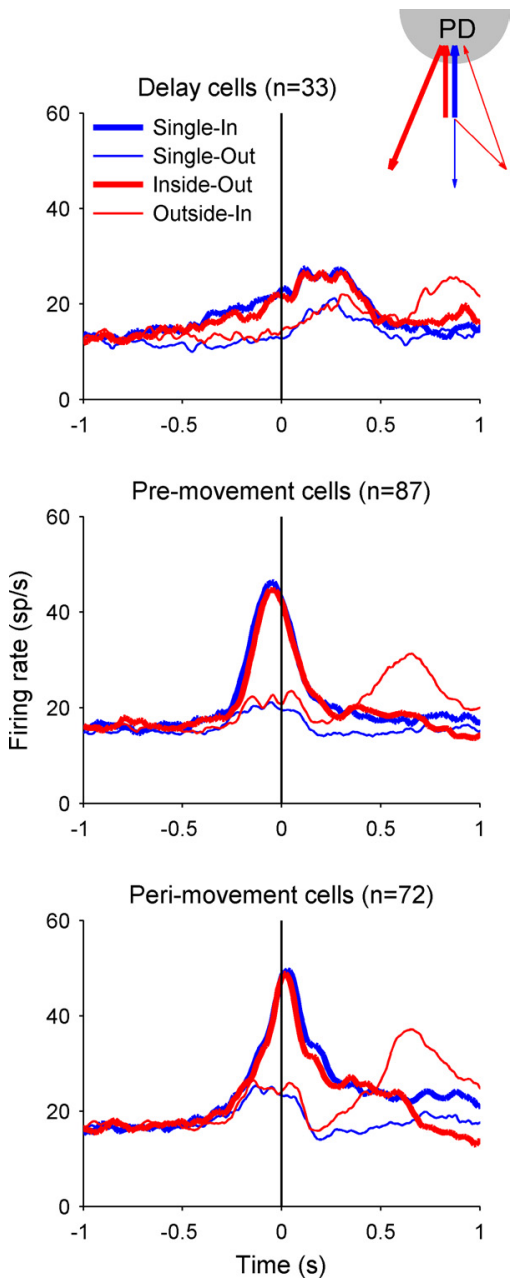

Figure 4. Population activity of area $5 \mathrm{~d}$ cells. Top, Firing rate averaged across the 33 cells with significant directional tuning during the delay period ( $400 \mathrm{~ms}$ before $\mathrm{G} 0$ ), aligned to the $\mathrm{G} 0$ signal. Middle, Bottom, The mean firing rates for the 87 premovement cells and 72 perimovement cells, respectively, both aligning to the first movement onset. Each panel plots the population activity for Single-In (blue thick line), Single-Out (blue thin line), Inside-Out (red thick line), and Outside-In (red thin line) conditions.

of the firing rate were well preserved in double-reach trials (Fig. 2; Table 1).

Figure 3 illustrates three representative cells, with each column showing activity of a typical neuron with significant directional tuning during the delay (Cell 1), premovement (Cell 2), or perimovement (Cell 3) period. The eight panels in each column show spike rasters and peristimulus time histograms (PSTHs) for activity when the monkey reached in directions indicated by the arrows during single- (blue) and double-reach (red) trials. For the delay neuron (Cell 1), the spike trains are aligned to the GO signal, and the cue period is indicated by the black bar. Before the GO signal, this cell increased its firing rate only when the first (immediate) reaching target was in the preferred direction (upleftward), whereas it exhibited little response when the cue for the first reach was presented in the nonpreferred direction, regardless of the location of the second reach goal. The middle and right columns show activity for a pre- (Cell 2) and perimovement (Cell 3) neuron, respectively, and the spike trains are aligned to movement onset. Similar to the delay cell, both the pre- and perimovement neurons increased firing rate only when the first (immediate) reaching target was in the preferred direction (mainly right-downward for the premovement cell and
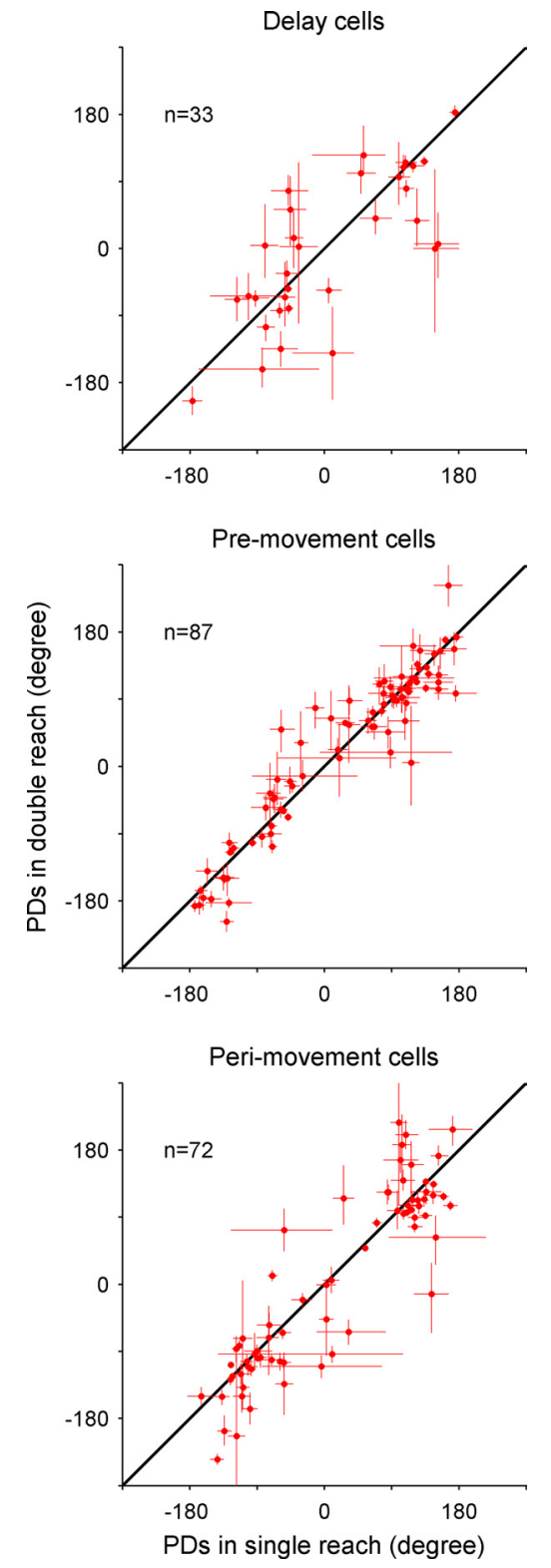

Figure 5. $P D$ in single-reach trials versus that of the first movement in double-reach trials. Scatter plots comparing the PDs of single- and double-reach trials in delay, premovement, and perimovement periods, respectively. The length of the bar on each circle represents the SE estimated with bootstrap method $(n=5000)$. The data points in all three plots are scattered along the unity line, indicating that PDs of area $5 \mathrm{~d}$ neurons before the first reach were not systematically modulated by the second movement.

upward for the perimovement cell). For all three cells, if the second reach was in an appropriate direction, but the cue for the first reach was presented in a nonpreferred direction, activity started to increase after the first reach was completed and the second was immediately impending.

To further characterize the neurons' activity in double reach, we examined firing rates in the following two conditions: the first target was in the preferred direction and the second target was in the nonpreferred direction (thick red line, referred as InsideOut); the first target was in a nonpreferred direction and the second target was in the preferred direction (thin red line, referred as Outside-In). Two control conditions were the singlereach trials in which the target was in the preferred direction and those in which the target was in a nonpreferred direction (thick 


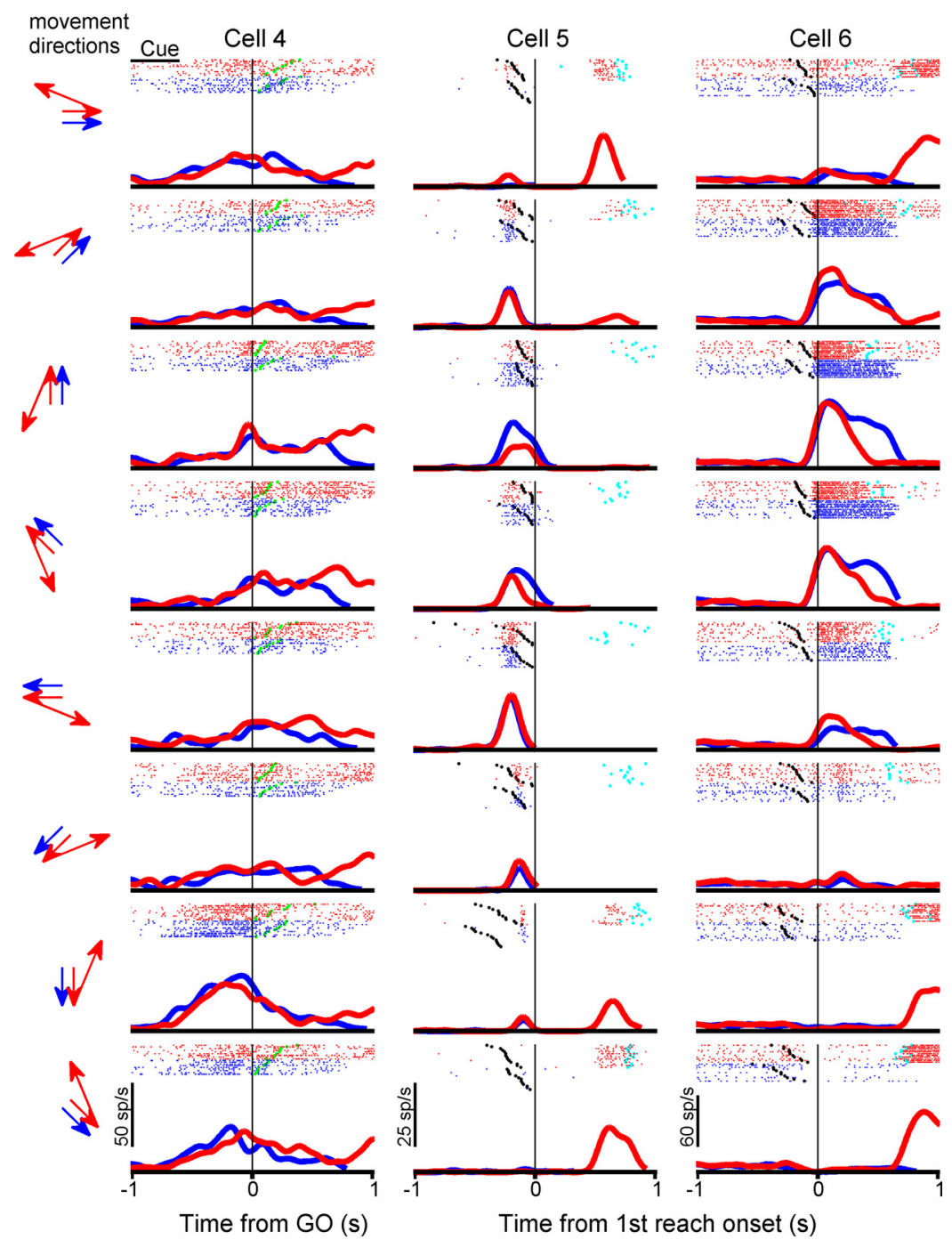

Figure 6. Three typical area $5 \mathrm{~d}$ cells recorded in free-view condition. Same conventions as Figure 3.

mean firing rate across all trials in one movement direction, $A$ is the baseline firing rate, $B$ is the directional modulation amplitude, $\Theta$ is the movement direction, and $\Theta_{0}$ is the PD of the neuron. In Figure 5 , each dot indicates the paired PDs of a neuron in single- versus double-reach trials for all three periods of interest. In the delay period, the mean PD difference between single and double reaching was $2.1^{\circ}\left[95 \%\right.$ confidence interval $=\left(-27.1^{\circ}\right.$ $\left.31.3^{\circ}\right) ; p>0.5$, circular $t$ test]. In the premovement period of the first movement, it was $0.1^{\circ}$ [95\% confidence interval $=$ $\left.\left(-8.1^{\circ} 8.2^{\circ}\right) ; p>0.5\right]$. In the perimovement period (Fig. 5, bottom), the PDs slightly shifted toward the second reach direction (mean difference in PDs = $9.2^{\circ}$ ), which might reflect a preparatory activity component related to the second reach in some cells. However, this shift was not statistically significant [ $95 \%$ confidence interval $\left.=\left(-2.9^{\circ} 21.3^{\circ}\right) ; p>0.1\right]$.

Because arm movements are often accompanied by coordinated eye movements in natural behavior, training a monkey to maintain central fixation during the double reach as in Fig. $1 A$ might influence the normal sequencing of serial movements. To eliminate effects of overtrained eye-hand dissociation, we recorded 139 area 5d cells ( 69 from monkey $A$ and 70 from monkey P) under a freeviewing condition before the monkeys were exposed to any tasks in which eye movements were controlled. In the freeview condition, monkeys performed the same arm movements as in Figure $1 A$, but were allowed to look anywhere they wanted during each trial (Fig. 1B). Examples of ac-

and thin blue lines, referred to as Single-In and Single-Out, respectively). For example, for Cell 1 in Figure 3, the firing rate was elevated during the delay period in the Inside-Out condition, but not in the Outside-In condition. Cell 2 in Figure 3 showed a burst of activity before the first movement onset in the Inside-Out condition, whereas it fired a burst before the second movement onset in the Outside-In condition.

Figure 4 plots the population-averaged PSTHs in the SingleIn, Single-Out, Inside-Out, and Outside-In conditions for the groups of cells with significant direction tuning in the delay (Fig. 4, top), the pre- (Fig. 4, middle), and perimovement (Fig. 4, bottom) periods. Similar to the individual cells shown in Figure 3, for the overall population of area $5 \mathrm{~d}$ cells the Single-In and Inside-Out conditions resulted in the similar pattern of activity through the completion of the first movement. For double-reach trials, the population activity was strongly elevated for InsideOut, but not for the Outside-In condition before the first reach, whereas it was not elevated until the second movement became immediate impending for the Outside-In condition.

To compare directional tuning between the single- and double-reach trials, we calculated the preferred direction (PD) for each neuron determined by fitting a cosine function (Georgopoulos et al., 1988): $r=A+B \times \cos \left(\Theta-\Theta_{0}\right)$, where $R$ is the tivity for three typical cells, population activity, and PDs are shown in Figures 6, 7A, and $8 A$ in the same conventions as Figures 3, 4, and 5 , respectively. Clearly, results in the free-view condition are very similar to the central fixation condition.

In the main task in Figure $1 A$, the second target was always $135^{\circ}$ counter-clockwise to the first, so one might argue that there was no real sequencing because of the fixed link between two targets. To eliminate this confounding issue and establish a flexible sequencing condition, we recorded 89 area $5 \mathrm{~d}$ cells from monkey A for the reach 2-from-3 condition (Fig. 1C), in which the second target (triangle) could be either counter-clockwise $\left(+120^{\circ}\right)$ or clockwise $\left(-120^{\circ}\right)$ to the first (square). The results (Figs. $7 B, 8 B$ ) also suggest that area 5 d activity is only dependent on the immediate next reach, and is insensitive to the subsequent movement or the visual distracter (data not shown).

To examine how the encoding of movement direction evolved during single- and double-reach trials, we adopted a population vector analysis algorithm proposed by Georgopoulos et al. (1988): the PD of each neuron was calculated by fitting the mean firing rate from -200 to $200 \mathrm{~ms}$ relative to movement onset during the single-reach trials. The resulting PDs and the instantaneous firing rates ( $\mathrm{bin}=50 \mathrm{~ms}$ ) were used to construct a time series of population vectors for each trial condition. Specifically, 
the weight of each neuron in a time point was calculated as the baseline-subtracted firing rate in a $50 \mathrm{~ms}$ time window sliding with $50 \mathrm{~ms}$ step. The resulting vector sum of all neurons' weights (baseline-subtracted firing rate) multiplied by the unit vector along their PDs was calculated as the instantaneous population vector.

The population vectors were computed separately for the two monkeys in all three conditions (Fig. 9A-C). Before movement initiation, the population vector gradually grew and pointed to the first reaching goal $\sim 200 \mathrm{~ms}$ before the first movement onset. After the initiation of the first movement, the population vector shortened to near zero. Then, it grew again, but aimed at the second target right before the second movement onset. In other words, the time-evolving population vector suggests that the spatiotemporal pattern of activity in area $5 \mathrm{~d}$ neurons carries directional information concerning the current unfolding reaching component in an arm movement sequence, whereas the encoded direction remains virtually invariant during the planning and execution of each elementary movement. Interestingly, not only was the population vector direction well preserved in double-reach trials, but so was the temporal profile of its amplitude. Because our sample size was too small to obtain sufficient and uniform PDs around each of the eight directions, the eight series of population vectors were collapsed into one (Pearce and Moran, 2012), as shown by the bold arrows on the left of Figure 9. Although collapsing the data might average out effects of second movement directions on activity before the first movements, if such effects were randomly distributed across cells, the population vectors should be shortened because of the counterbalanced components related to second reaches. However, the virtually identical amplitudes of the population vectors for single- and doublereach trials demonstrate that this is not the case.

In principle, it is possible that the two participating monkeys might have adopted a special strategy to sequentially plan single reaches rather than a coherent double reach, which might also explain the cortical presentation of immediate movement observed in the present study. To ensure that the monkeys actually prepared a sequential reach rather than planning the movements one reach at a time, we compared the end-point variability of the first and second reaches. The results demonstrate that the endpoint variability of the second reach $\left(\mathrm{SD}=9.1^{\circ}, n=3234\right.$ for monkey $\mathrm{A} ; \mathrm{SD}=7.7^{\circ}, n=3208$ for monkey $\mathrm{P}$ ) was even smaller than for the first reach $\left(\mathrm{SD}=9.6^{\circ}\right.$ and $9.9^{\circ}$ for monkeys $\mathrm{A}$ and $\mathrm{P}$, respectively; $p<0.001$ for both monkeys, $F$ test), although both are larger than the single-reach trials $\left(\mathrm{SD}=8.3^{\circ} ; n=3217\right.$ for monkey $\mathrm{A} ; \mathrm{SD}=6.3^{\circ}, n=3221$ for monkey $\mathrm{P} ; p<0.001$ for both monkeys, $F$ test), consistent with the expectation of suboptimal performance during sequential movements (Wu et al., 2009). If two reaches were individually planned one after the other, the end-point variability should have accumulated. Furthermore, because both targets disappeared before the motor execution, it is highly unlikely that the second reaching goal was accurately memorized, but not used for guiding movement until the first reach was completed. Therefore, the behavioral analysis strongly suggests that the whole reaching sequence was planned in a coordinated manner before the movement initiation.

Although the second reach began from a different limb position and had a larger amplitude than the first and single reaches, the characteristics of the related activity are still of interest. Figures 10 and 11 compare single-neuron and population activity around the second reach with that during single reaches aiming at the same locations. Clearly, both the representative single cells and the entire population exhibited markedly increased activity when the second movement was directed toward the PD of the neurons. To determine whether activity at the moment encodes the component movement vector or the goal location in extrapersonal space, we directly compared the PDs of single reach with the second movement in double reach (Fig. 12). Because the second movement direction was always rotated $22.5^{\circ}$ from the 
A

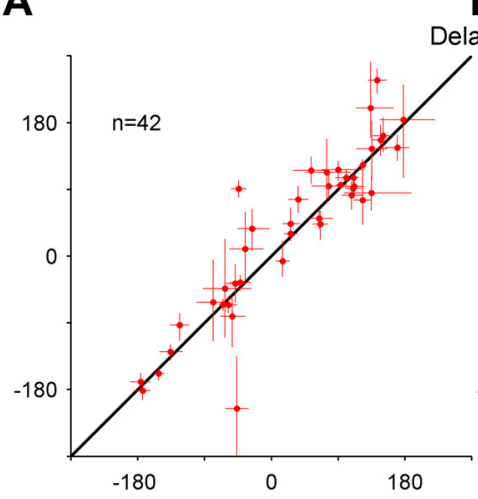

B

elay cells
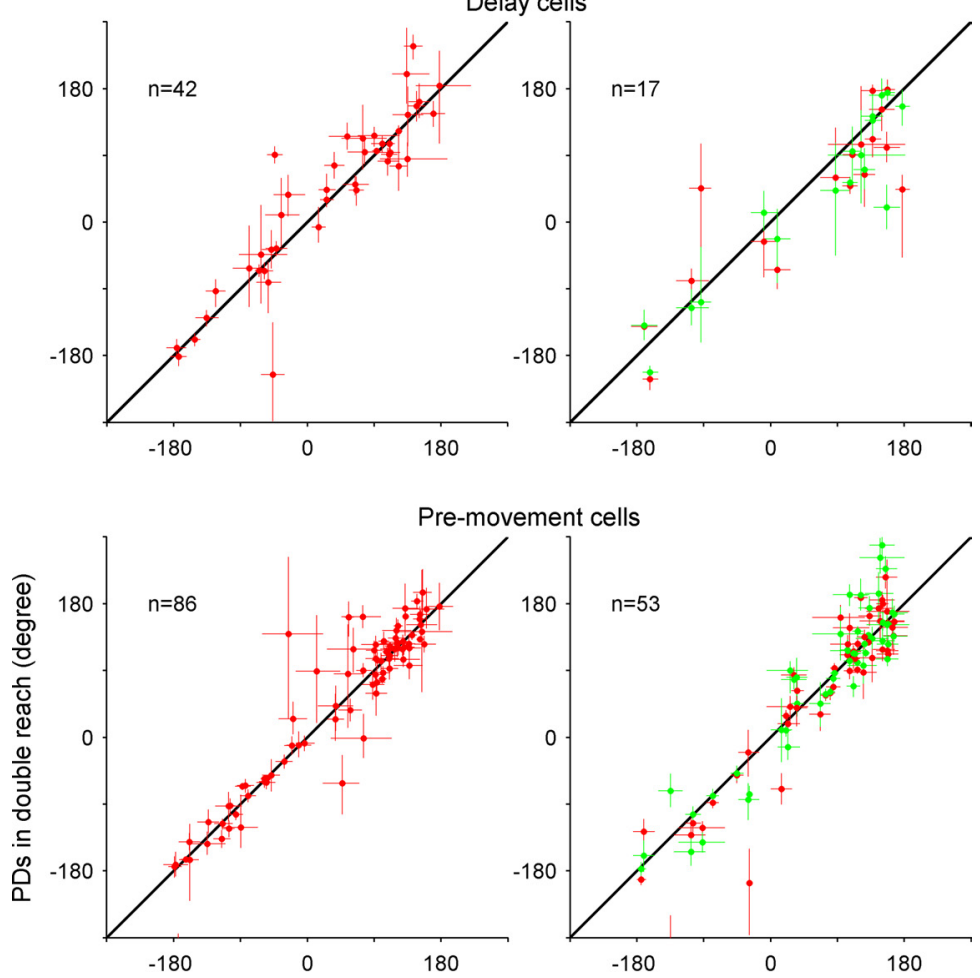

ovement cells
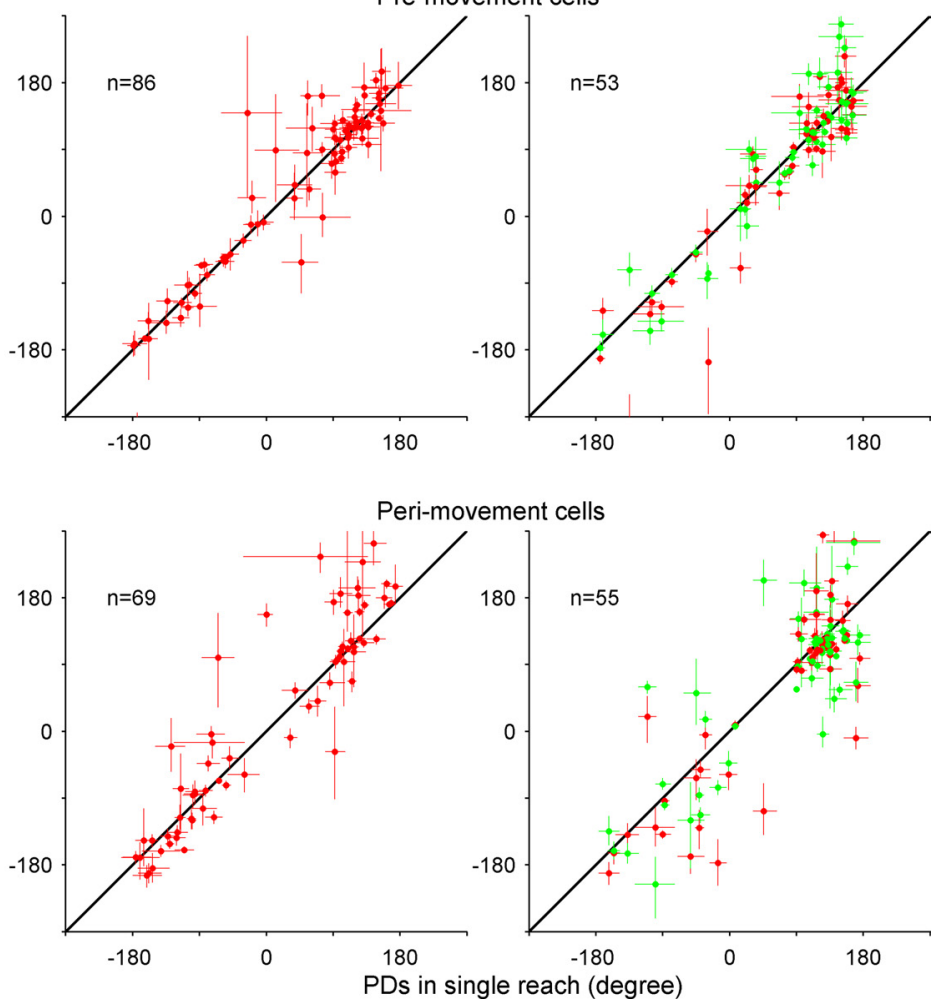

Figure 8. PDs in single-reach trials versus those of the first movement in double-reach trials for area $5 \mathrm{~d}$ cells recorded in the free-view condition $(\boldsymbol{A})$ and Reach-2-from-3 condition $(\boldsymbol{B})$. Scatter plots comparing the PDs of single- and double-reach trials in delay, premovement, and perimovement periods, respectively. The red dots indicate that the second target was $\mathrm{CCW}$ to the first target, while the green dots represent CW displacement. The length of the bar on each circle represents the SE.

single reach (Fig. 10, left), the PDs should be shifted accordingly at the population level if the reach vector was constantly encoded. However, our results reveal no such shift with the movement vector.

\section{Discussion}

In the present study, we examined neuronal activity in area $5 \mathrm{~d}$ while the monkeys performed a memory-guided double reach task requiring them to approach two simultaneously presented targets in a specified order. The results suggest that at any given time during the task, responses in area $5 \mathrm{~d}$ only convey information regarding the immediate next reach, and not about the entire sequence of movements. The directional tuning of area $5 \mathrm{~d}$ cells during the delay period only reflected the first reach goal, regardless of the location of the second goal. In the temporal domain, the directional tuning of area $5 \mathrm{~d}$ cells to the first and second reaching goals rose sequentially with the unfolding of the motor sequence, and the population vector constructed from the assemble activity of area $5 \mathrm{~d}$ neurons pointed to the direction of the immediate upcoming reach. The remarkably congruent activity between single reaches and the first reach of double reaches suggests that area $5 \mathrm{~d}$ is closely coupled to the planning of discrete reaching arm movements, as opposed to the motor sequence encoded in other cortical sensorimotor areas. Because it has been previously demonstrated that elevated area 5 activity occurs far before the earliest increase in electromyographic activity, which rules out feedback from proprioceptors or motoneurons (Kalaska and Crammond, 1995), area 5d is likely involved in motor planning. The elementary movement encoded in area $5 \mathrm{~d}$ suggests that decomposition of the motor sequence might emerge within the parietal-frontal network, instead of being exclusively implemented by descending corticosubcortical and corticospinal circuits. Nevertheless, our current results do not prove that area $5 \mathrm{~d}$ is the only cortical area conveying component movement, or that the unfolding of the motor sequence occurs in area $5 \mathrm{~d}$. The apparent difference between area $5 \mathrm{~d}$ and other brain regions requires further validation by simultaneous recordings from the same animals to eliminate confounding factors such as training history, behavioral strategy, level of performance, etc.

Before the second reach, we found no movement-vector-based shift in directional tuning of area $5 \mathrm{~d}$ cells, which is consistent with coding of goal location. Of course, this interpretation is based on the assumption that directional tuning is invariant with movement distance and starting point, but in fact, both factors have been found to strikingly influence directional selectivity in sensorimotor cortex. For example, directional tuning of M1 cells has been reported to vary with reach distance (Churchland and Shenoy, 2007). Even though some recent evidence supports the idea that area $5 \mathrm{~d}$ encodes handcentered reach vectors, activity is still strongly affected by initial hand position (Bremner and Andersen, 2012). If area 5d activity is gain-modulated by hand position in a systematic manner, as reported for other areas (Pesaran et al., 2006; Chang et al., 2009), its directional tuning might also be distorted profoundly. Thus, the essential characteristics of the activity related to the second reach remain uncertain.

As an important sensorimotor interface, the PPC has received surprisingly little attention in sequential planning, although it presumably is involved in serial behaviors. Damage to the left parietal lobe in the human can cause a neurological disorder called ideational apraxia. Patients so impaired have no problem in performing elementary movements, but lose the ability to con- 

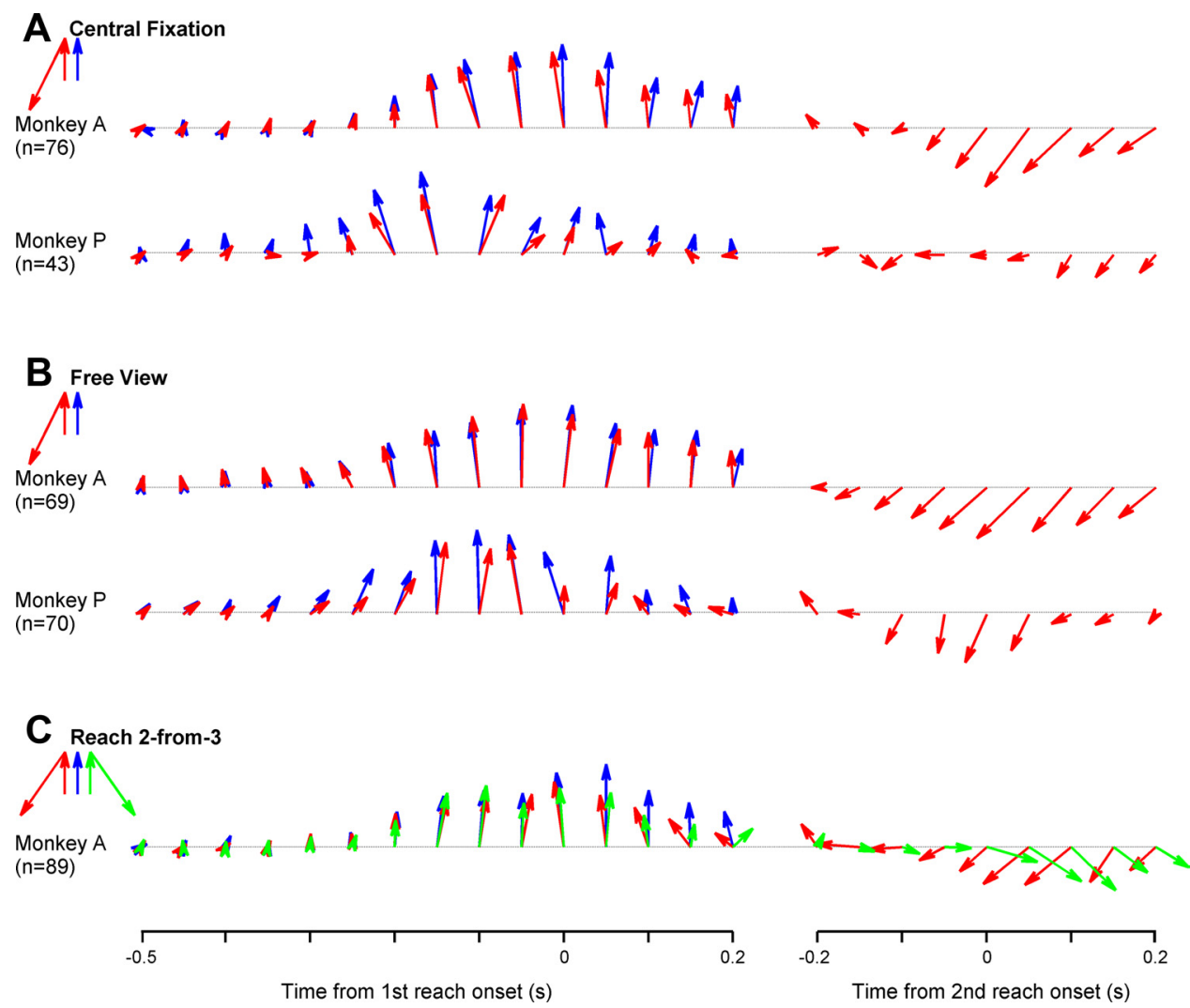

Figure 9. Time series of population vectors. $A$, Population vector decoded from cells sampled from monkey A and $P$ in single- (blue) and double-reaches (red) under the central-fixation condition (Fig. 1A). B, Population vector decoded from cells sampled from monkey A and P in single (blue) and double-reaches (red) under the free-view condition (Fig. 1B). C, Population vector decoded from cells sampled from monkey A in single (blue), CW double- (green), and CCW double-reaches (red) in the reach 2-from-3 condition (Fig. 1C).

ceptualize utilization of objects, and to plan and execute complex series of motor actions to manipulate these objects (Buxbaum, 1998; Zadikoff and Lang, 2005), indicating that the PPC might play a key role in transforming multiple targets into a sequential motor response. At the early stage of transforming visual information into motor intention, the PRR encodes high-level reach plans in visual coordinates (Batista et al., 1999), and has been found to carry information of both immediate and subsequent goals for sequential reaching arm movements (Baldauf et al., 2008). To activate muscle synergies, an abstract action sequence must be decomposed into serial motor commands while visual targets must be integrated with information about hand position and intrinsic arm posture (Kalaska et al., 1997), because accurate motor control must take into account intrinsic biomechanics of the musculoskeletal system via both efference copy and sensory feedback to implement an optimal state estimation (Wolpert and Kawato, 1998; Körding and Wolpert, 2004; Shadmehr and Wise, 2005; Sober and Sabes, 2005). In contrast to the PRR, area 5d incorporates proprioceptive information in conjunction with visual inputs (Shi et al., 2013) to form a hand- or body-related reaching plan (Ferraina and Bianchi, 1994; Lacquaniti et al., 1995; Buneo et al., 2002; Bremner and Andersen, 2012). Our present study demonstrates that area $5 \mathrm{~d}$ activity is tightly coupled only to the next upcoming movement, suggesting it might play a key role in integrating the abstract goal with the physical limb to implement inverse kinematics and form an internal model. The differences between area $5 \mathrm{~d}$ and the PRR/LIP (lateral intraparietal area) in sequential planning, as well as in effector choice (Cui and Andersen, 2007, 2011) and proactive movement (Maimon and Assad, 2006), indicate that the PPC is involved in sensorimotor integration at multiple levels, instead of providing a unified associative map. However, sequential behavior engages a highly distributed network within the cortical-subcortical circuitry (Hikosaka et al., 1999; Tanji, 2001), so it remains an open question how the PPC interacts with frontal areas and subcortical structures.

As with frontal motor areas, a large body of evidence indicates that area $5 \mathrm{~d}$ activity is also influenced by hand velocity, arm posture (Georgopoulos et al., 1984; Ferraina and Bianchi, 1994; Scott et al., 1997), approach style, and anticipated physical characters of objects, etc. (Ashe and Georgopoulos, 1994; Averbeck et al., 2005; Chen et al., 2009; Grafton, 2010). In addition, it has been observed that area 5 activity conveys behavioral context information such as the number of self-movement repetitions (Sawamura et al., 2002). Moreover, although abstract and effector-specific sequential representations have been revealed in separate brain areas, and sequential timing is independent of muscle commands (Grafton et al., 1998), timing structure might still modulate movement (Kornysheva et al., 2013). Both the first and second movement in double reach are inherently different from single reach in many kinematic (e.g., speed and accuracy etc.) and cognitive (e.g., temporal order, cost, and reward etc.) factors, which might cause slight differences both in activity and population vectors between single- and doublereach trials.

Area $5 \mathrm{~d}$ receives major cortical inputs from somatosensory areas (Jones et al., 1978; Pearson and Powell, 1985), and is reciprocally interconnected with M1 and premotor cortex (PM; Strick and Kim, 1978). Neural activity in area 5 and motor cortex exhibits similar correlations with kinematic variables (Ashe and Georgopoulos, 1994). Compared with M1, area 5d cells start to 


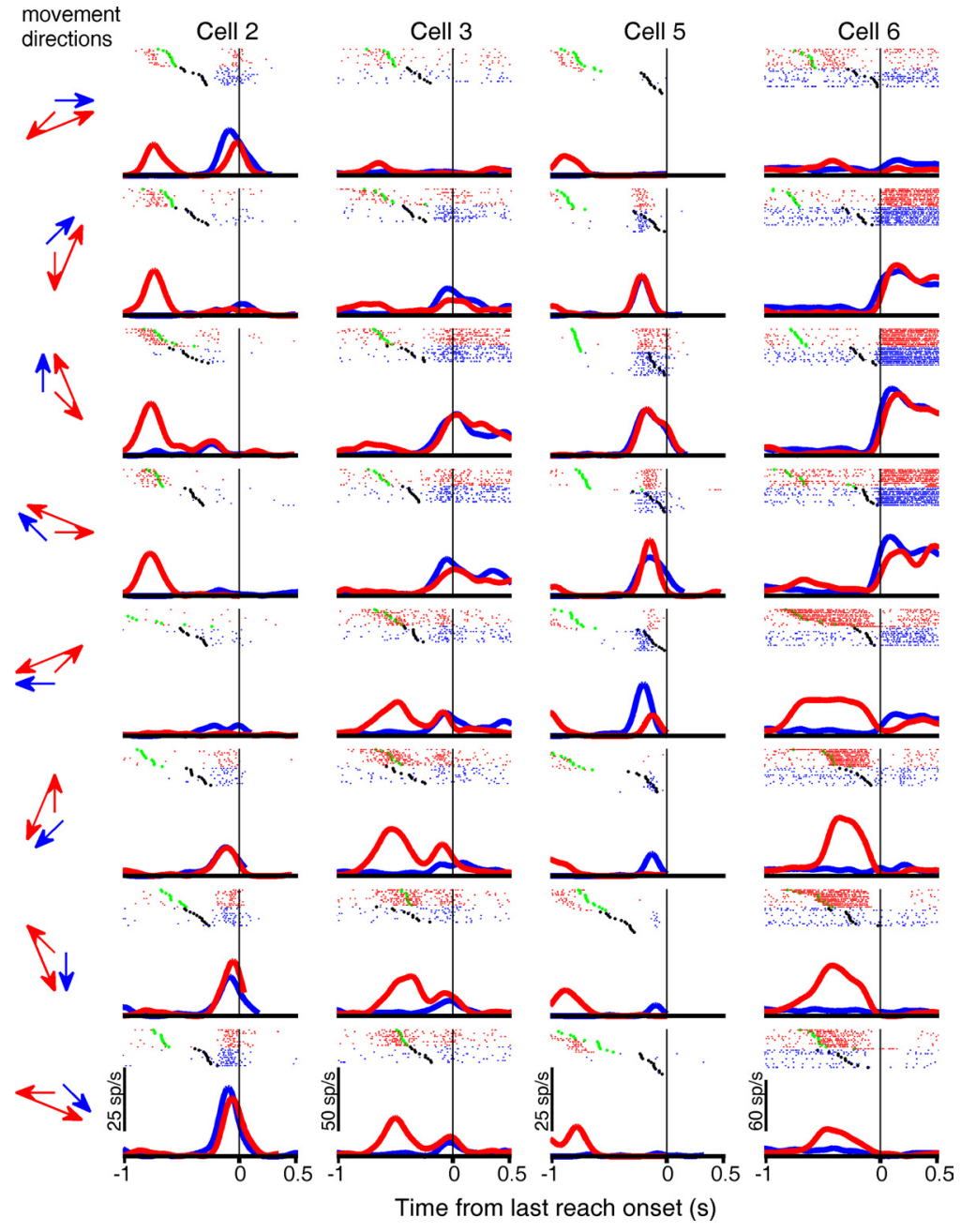

Figure 10. Comparison of activity of four representative area $5 \mathrm{~d}$ cells between single-reach trials and the second movement during double-reach trials. As in Figures 3 and 6, blue and red indicate results from single- and double-reach trials, respectively. The black and green dots mark the G0 signal and the first movement onset, respectively. However, in contrast to those figures, each panel presents activity for one single-reach (blue) and one double-reach (red) condition with movement directions indicated by arrows on the left, so that movements aimed the same location are compared, instead of those launched along the same direction. In addition, spike rasters in double-reach trials (red) were aligned to the second movement onset. Because there was no delay period for the second reach, only four cells with pre- and perimovement tuning (Cells 2 and 3 from Fig. 3, and Cells 5 and 6 from Fig. 6) are shown here.

fire later (Kalaska et al., 1983) and are insensitive to the kinetic characteristics of movements (Kalaska et al., 1990; Hamel-Pâquet et al., 2006). At first glance, it seems plausible that area $5 \mathrm{~d}$ simply receives efference copy information from M1. However, the present study reveals compelling evidence that area $5 \mathrm{~d}$ activity is only related to the immediate reach, and not subsequent movements as in M1 (Kettner et al., 1996a,b; Lu and Ashe, 2005) and PM (Mushiake et al., 1991; Shanechi et al., 2012). When monkeys moved their arms to approach targets with a mentally calculated "L" shape orthogonal bend, the population vector of M1 cells was found to point first to the final goal location, and then to rotate toward the initial movement direction (Ashe et al., 1993). Moreover, unlike markedly oscillatory activity in M1 (Churchland et al., 2012), area $5 \mathrm{~d}$ activity exhibits virtually no rhythmic component (Buneo et al., 2003), but instead provides reliable firing rate information (Maimon and Assad, 2009). Together, these observations suggest that area $5 \mathrm{~d}$ does not simply mirror $\mathrm{M} 1$ and/or PM, but instead plays an active role as an internal feedforward model in joint/muscle coordinates and/or provides an optimal state estimation of the limb for online control (Wolpert et al., 1998; Desmurget and Grafton, 2000; Mulliken et al., 2008; Archambault et al., 2009). On the other hand, the encoding of component movements in area 5d implies neither that the motor sequence is decomposed in area $5 \mathrm{~d}$, nor that it is hierarchically downstream to M1. As the primary origin of descending projections to the spinal cord and brainstem (Wise et al., 1997; Alstermark and Isa, 2012), M1 presumably plays a predominate role in issuing motor commands, whereas area $5 \mathrm{~d}$ probably functions in parallel with M1, providing feedforward limb state estimations for the component reaches to guide and correct subsequent movements. Of course, it is premature to designate specific roles across brain areas based on results obtained under different behavioral conditions. For example, the apparent difference in population vectors between the present study and Ashe et al. (1993) might also be explained by differences in the tasks: both reaching goals were explicitly presented at the beginning of each trial in this study, whereas the monkeys had to mentally calculate the launching direction from the final goal location in Ashe et al. (1993). A more definitive answer to the question of how M1 and area $5 \mathrm{~d}$ interact during sequential behavior will require studies that use the same animals and behavioral paradigms.

\section{References}

Alstermark B, Isa T (2012) Circuits for skilled reaching and grasping. Annu Rev Neurosci 35: 559-578. CrossRef Medline

Archambault PS, Caminiti R, Battaglia-Mayer A (2009) Cortical mechanisms for online control of hand movement trajectory: the role of the posterior parietal cortex. Cereb Cortex 19: 2848-2864. CrossRef Medline

Ashe J, Georgopoulos AP (1994) Movement parameters and neural activity in motor cortex and area 5. Cereb Cortex 4:590-600. CrossRef Medline

Ashe J, Taira M, Smyrnis N, Pellizzer G, Georgakopoulos T, Lurito JT, Georgopoulos AP (1993) Motor cortical activity preceding a memorized movement trajectory with an orthogonal bend. Exp Brain Res 95:118-130. Medline

Averbeck BB, Chafee MV, Crowe DA, Georgopoulos AP (2005) Parietal representation of hand velocity in a copy task. J Neurophysiol 93:508-518. Medline

Averbeck BB, Sohn JW, Lee D (2006) Activity in prefrontal cortex during dynamic selection of action sequences. Nat Neurosci 9:276282. CrossRef Medline

Baldauf D (2011) Chunking movements into sequence: the visual preselection of subsequent goals. Neuropsychologia 49:1383-1387. CrossRef Medline

Baldauf D, Cui H, Andersen RA (2008) The posterior parietal cortex encodes in parallel both goals for double-reach sequences. J Neurosci 28: 10081-10089. CrossRef Medline

Batista AP, Buneo CA, Snyder LH, Andersen RA (1999) Reach plans in eyecentered coordinates. Science 285:257-260. CrossRef Medline

Bremner LR, Andersen RA (2012) Coding of the reach vector in parietal area 5d. Neuron 75:342-351. CrossRef Medline 
A

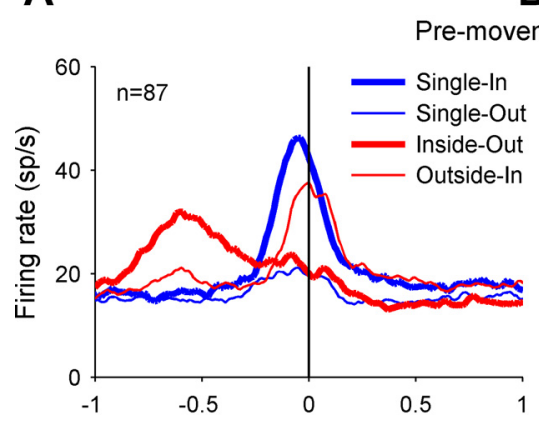

B

Peri-movement cells

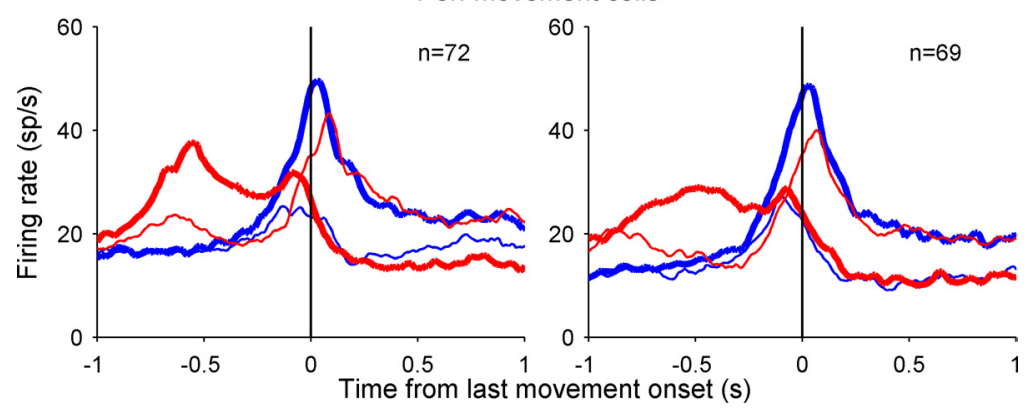

Figure 11. Comparison of population activity of area $5 \mathrm{~d}$ cells between single-reach trials and the second movement of doublereach trials in the central fixation $(\boldsymbol{A})$ and free-view conditions $(\boldsymbol{B})$. Top, Bottom, Mean firing rates for the premovement and perimovement cells, respectively. Each panel plots the population activity for Single-In (blue thick line), Single-Out (blue thin line), Inside-Out (red thick line), and Outside-In (red thin line) conditions. Unlike Figures 4 and 7, the activity curves for the double-reach trials are aligned to the second movement onset.

Buneo CA, Jarvis MR, Batista AP, Andersen RA (2002) Direct visuomotor transformations for reaching. Nature 416:632-636. CrossRef Medline

Buneo CA, Jarvis MR, Batista AP, Andersen RA (2003) Properties of spike train spectra in two parietal reach areas. Exp Brain Res 153:134-139. CrossRef Medline

Buxbaum LJ (1998) Ideational apraxia and naturalistic action. Cogn Neuropsychol 15:617-643. CrossRef Medline

Carpenter AF, Georgopoulos AP, Pellizzer G (1999) Motor cortical encoding of serial order in a context-recall task. Science 283:1752-1757. CrossRef Medline

Chang SW, Papadimitriou C, Snyder LH (2009) Using a compound gain field to compute a reach plan. Neuron 64:744-755. CrossRef Medline

Chen J, Reitzen SD, Kohlenstein JB, Gardner EP (2009) Neural representation of hand kinematics during prehension in posterior parietal cortex of the macaque monkey. J Neurophysiol 102:3310-3328. CrossRef Medline

Churchland MM, Shenoy KV (2007) Temporal complexity and heterogeneity of single-neuron activity in premotor and motor cortex. J Neurophysiol 97:4235-4257. CrossRef Medline

Churchland MM, Cunningham JP, Kaufman MT, Ryu SI, Shenoy KV (2010) Cortical preparatory activity: representation of movement or first cog in a dynamical machine? Neuron 68:387-400. CrossRef Medline

Churchland MM, Cunningham JP, Kaufman MT, Foster JD, Nuyujukian P, Ryu SI, Shenoy KV (2012) Neural population dynamics during reaching. Nature 487:51-56. CrossRef Medline

Cisek P, Kalaska JF (2010) Neural mechanisms for interacting with a world full of action choices. Annu Rev Neurosci 33:269-298. CrossRef Medline

Cui H, Andersen RA (2007) Posterior parietal cortex encodes autonomously selected motor plans. Neuron 56:552-559. CrossRef Medline

Cui H, Andersen RA (2011) Different representations of potential and selected motor plans by distinct parietal areas. J Neurosci 31:18130-18136. CrossRef Medline

Desmurget M, Grafton S (2000) Forward modeling allows feedback control for fast reaching movements. Trends Cogn Sci 4:423-431. CrossRef Medline

Ferraina S, Bianchi L (1994) Posterior parietal cortex: functional properties of neurons in area 5 during an instructed-delay reaching task within different parts of space. Exp Brain Res 99:175-178. Medline
Filimon F, Nelson JD, Huang RS, Sereno MI (2009) Multiple parietal reach regions in humans: cortical representations for visual and proprioceptive feedback during on-line reaching. J Neurosci 29:2961-2971. CrossRef Medline

Fujii N, Graybiel AM (2003) Representation of action sequence boundaries by macaque prefrontal cortical neurons. Science 301:12461249. CrossRef Medline

Georgopoulos AP, Caminiti R, Kalaska JF (1984) Static spatial effects in motor cortex and area 5: quantitative relations in a two-dimensional space. Exp Brain Res 54:446-454. Medline

Georgopoulos AP, Kettner RE, Schwartz AB (1988) Primate motor cortex and free arm movements to visual targets in threedimensional space: II. Coding of the direction of movement by a neuronal population. J Neurosci 8:2928-2937. Medline

Grafton ST (2010) The cognitive neuroscience of prehension: recent developments. Exp Brain Res 204:475-491. CrossRef Medline

Grafton ST, Hazeltine E, Ivry RB (1998) Abstract and effector-specific representations of motor sequences identified with PET. J Neurosci 18:9420-9428. Medline

Hamel-Pâquet C, Sergio LE, Kalaska JF (2006) Parietal area 5 activity does not reflect the differential time-course of motor output kinetics during arm-reaching and isometric-force tasks. J Neurophysiol 95:3353-3370. CrossRef Medline

Hatsopoulos NG, Suminski AJ (2011) Sensing with the motor cortex. Neuron 72:477-487. CrossRef Medline

He SQ, Dum RP, Strick PL (1993) Topographic organization of corticospinal projections from the frontal lobe: motor areas on the lateral surface of the hemisphere. J Neurosci 13:952-980. Medline

Heed T, Beurze SM, Toni I, Röder B, Medendorp WP (2011) Functional rather than effector-specific organization of human posterior parietal cortex. J Neurosci 31:3066-3076. CrossRef Medline

Hikosaka O, Nakahara H, Rand MK, Sakai K, Lu X, Nakamura K, Miyachi S, Doya K (1999) Parallel neural networks for learning sequential procedures. Trends Neurosci 22:464-471. CrossRef Medline

Histed MH, Miller EK (2006) Microstimulation of frontal cortex can reorder a remembered spatial sequence. PLoS Biol 4:e134. CrossRef Medline

Ivry RB, Spencer RM (2004) The neural representation of time. Curr Opin Neurobiol 14:225-232. CrossRef Medline

Jones EG, Coulter JD, Hendry SH (1978) Intracortical connectivity of architectonic fields in the somatic sensory, motor and parietal cortex of monkeys. J Comp Neurol 181:291-347. CrossRef Medline

Kalaska JF, Crammond DJ (1995) Deciding not to GO: neuronal correlates of response selection in a GO/NOGO task in primate premotor and parietal cortex. Cereb Cortex 5:410-428. CrossRef Medline

Kalaska JF, Caminiti R, Georgopoulos AP (1983) Cortical mechanisms related to the direction of two-dimensional arm movements: relations in parietal area 5 and comparison with motor cortex. Exp Brain Res 51:247260. Medline

Kalaska JF, Cohen DA, Prud'homme M, Hyde ML (1990) Parietal area 5 neuronal activity encodes movement kinematics, not movement dynamics. Exp Brain Res 80:351-364. Medline

Kalaska JF, Scott SH, Cisek P, Sergio LE (1997) Cortical control of reaching movements. Curr Opin Neurobiol 7:849-859. CrossRef Medline

Keele SW, Ivry R, Mayr U, Hazeltine E, Heuer H (2003) The cognitive and neural architecture of sequence representation. Psychol Rev 110: 316-339. CrossRef Medline

Kettner RE, Marcario JK, Clark-Phelps MC (1996a) Control of remembered reaching sequences in monkey: I. Activity during movement in motor and premotor cortex. Exp Brain Res 112:335-346. CrossRef Medline

Kettner RE, Marcario JK, Port NL (1996b) Control of remembered reaching sequences in monkey: II. Storage and preparation before movement in 
A

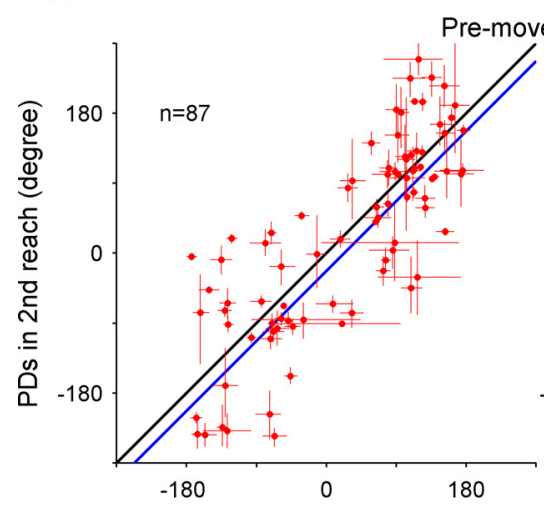

B
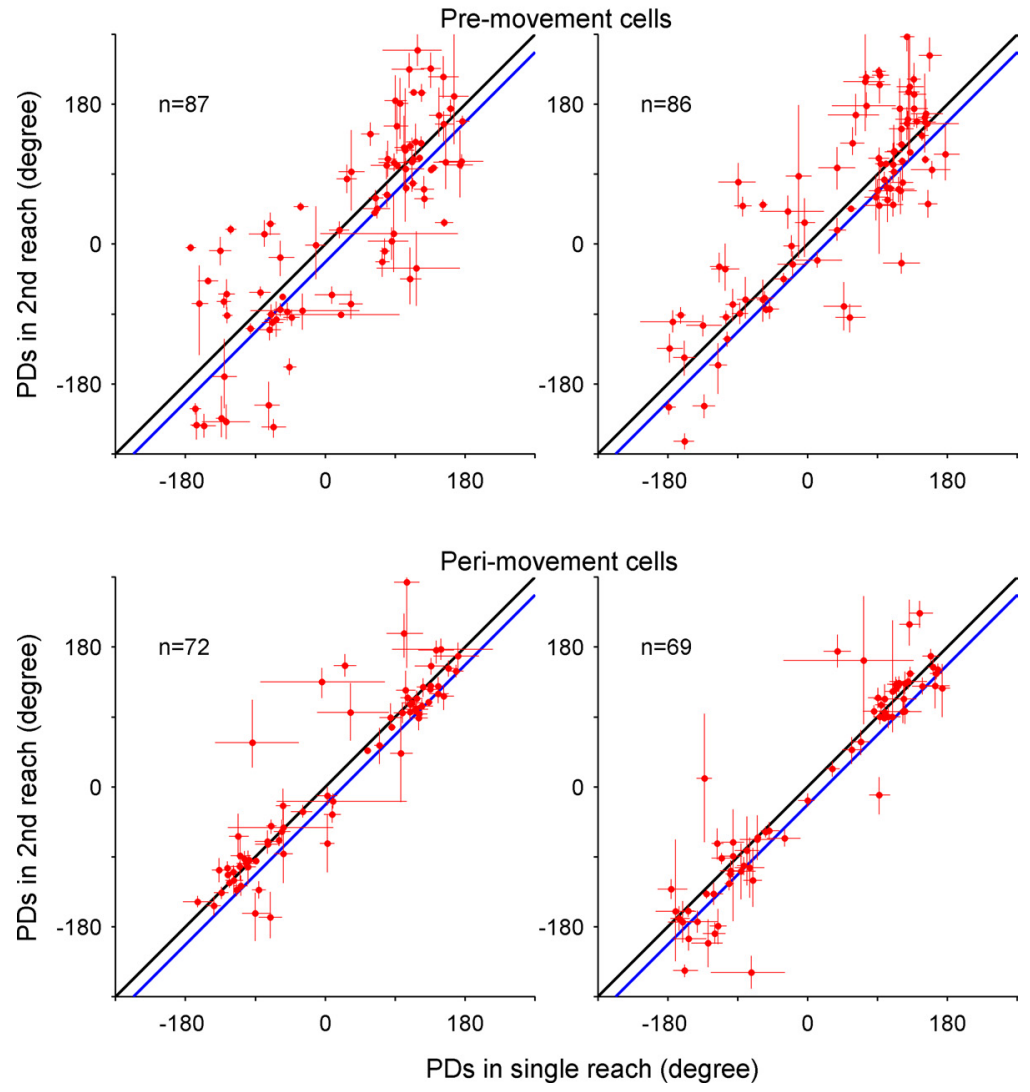

Figure 12. PDs in single-reach trials versus those of the second movement during double-reach trials in the central fixation $(\boldsymbol{A})$ and free-view condition $(\boldsymbol{B})$. Top, Bottom, Scatter plots comparing the PDs of single reaches and second movements in doublereach trials in premovement and perimovement periods, respectively, calculated based on the direction of the movement goal relative to the center. The length of the bars on each circle represents SES, estimated with a bootstrap method $(n=5000)$. The black and blue diagonal lines indicate the $0^{\circ}$ and $22.5^{\circ}$ differences between the PDs for second reach and single reaches. The scattered points are not significantly shifted from the black (unity) line ( $p>0.1$, circular $t$ test), whereas, with the exception of $\boldsymbol{A}$ $(p>0.1)$, they are significantly shifted above the blue line $(p<0.01)$.

motor and premotor cortex. Exp Brain Res 112:347-358. CrossRef Medline

Körding KP, Wolpert DM (2004) Bayesian integration in sensorimotor learning. Nature 427:244-247. CrossRef Medline

Kornysheva K, Sierk A, Diedrichsen J (2013) Interaction of temporal and ordinal representations in movement sequences. J Neurophysiol 109: 1416-1424. CrossRef Medline

Lacquaniti F, Guigon E, Bianchi L, Ferraina S, Caminiti R (1995) Representing spatial information for limb movement: role of area 5 in the monkey. Cereb Cortex 5:391-409. CrossRef Medline

Lu X, Ashe J (2005) Anticipatory activity in primary motor cortex codes memorized movement sequences. Neuron 45:967-973. CrossRef Medline

Maimon G, Assad JA (2006) A cognitive signal for the proactive timing of action in macaque LIP. Nat Neurosci 9:948-955. CrossRef Medline

Maimon G, Assad JA (2009) Beyond Poisson: increased spike-time regularity across primate parietal cortex. Neuron 62:426-440. CrossRef Medline

Massey JT, Schwartz AB, Georgopoulos AP (1986) On information processing and performing a movement sequence. Exp Brain Res 15:242-251.

Matelli M, Luppino G (2001) Parietofrontal circuits for action and space perception in the macaque monkey. Neuroimage 14:27-32. CrossRef Medline

Medendorp WP, Goltz HC, Crawford JD, Vilis T (2005) Integration of target and effector information in human posterior parietal cortex for the planning of action. J Neurophysiol 93:954-962. CrossRef Medline

Mulliken GH, Musallam S, Andersen RA (2008) Forward estimation of movement state in posterior parietal cortex. Proc Natl Acad Sci U S A 105:8170-8177. CrossRef Medline

Mushiake H, Inase M, Tanji J (1991) Neuronal activity in the primate pre- motor, supplementary, and precentral motor cortex during visually guided and internally determined sequential movements. J Neurophysiol 66:705-718. Medline

Ohbayashi M, Ohki K, Miyashita Y (2003) Conversion of working memory to motor sequence in the monkey premotor cortex. Science 301:233-236. CrossRef Medline

Pearce TM, Moran DW (2012) Strategy-dependent encoding of planned arm movements in the dorsal premotor cortex. Science 337:984988. CrossRef Medline

Pearson RC, Powell TP (1985) The projection of the primary somatic sensory cortex upon area 5 in the monkey. Brain Res 356:89-107. Medline

Pesaran B, Nelson MJ, Andersen RA (2006) Dorsal premotor neurons encode the relative position of the hand, eye, and goal during reach planning. Neuron 51:125-134. CrossRef Medline

Quian Quiroga R, Nadasdy Z, Ben-Shaul Y (2004) Unsupervised spike detection and sorting with wavelets and superparamagnetic clustering. Neural Comput 16:1661-1687. CrossRef Medline

Rathelot JA, Strick PL (2006) Muscle representation in the macaque motor cortex: an anatomical perspective. Proc Natl Acad Sci U S A 103:8257-8262. CrossRef Medline

Sawamura H, Shima K, Tanji J (2002) Numerical representation for action in the parietal cortex of the monkey. Nature 415:918-922. CrossRef Medline

Scott SH, Sergio LE, Kalaska JF (1997) Reaching movements with similar hand paths but different arm orientations: II. Activity of individual cells in dorsal premotor cortex and parietal area 5. J Neurophysiol 78:2413-2426. Medline

Shadmehr R, Wise SP (2005) The computational neurobiology of reaching and pointing: a foundation for motor learning. Cambridge, MA: MIT.

Shanechi MM, Hu RC, Powers M, Wornell GW, Brown EN, Williams ZM (2012) Neural population partitioning and a concurrent brain-machine interface for sequential motor function. Nat Neurosci 15:1715-1722. CrossRef Medline

Shi Y, Apker G, Buneo CA (2013) Multimodal representation of limb endpoint position in the posterior parietal cortex. J Neurophysiol 109:20972107. CrossRef Medline

Shima K, Isoda M, Mushiake H, Tanji J (2007) Categorization of behavioural sequences in the prefrontal cortex. Nature 445:315-318. CrossRef Medline

Sober SJ, Sabes PN (2005) Flexible strategies for sensory integration during motor planning. Nat Neurosci 8:490-497. CrossRef Medline

Straw AD (2008) Vision egg: an open-source library for realtime visual stimulus generation. Front Neuroinform 2:4. CrossRef Medline

Strick PL, Kim CC (1978) Input to primate motor cortex from posterior parietal cortex (area 5): I. Demonstration by retrograde transport. Brain Res 157:325-330. CrossRef Medline

Tanji J (2001) Sequential organization of multiple movements: involvement of cortical motor areas. Annu Rev Neurosci 24:631-651. CrossRef Medline

Tanji J, Shima K (1994) Role for supplementary motor area cells in planning several movements ahead. Nature 371:413-416. CrossRef Medline

Wise SP, Boussaoud D, Johnson PB, Caminiti R (1997) Premotor and parietal cortex: corticocortical connectivity and combinatorial computations. Annu Rev Neurosci 20:25-42. CrossRef Medline

Wolpert DM, Kawato M (1998) Multiple paired forward and inverse models for motor control. Neural Netw 11:1317-1329. CrossRef Medline

Wolpert DM, Goodbody SJ, Husain M (1998) Maintaining internal repre- 
sentations: the role of the human superior parietal lobe. Nat Neurosci 1:529-533. CrossRef Medline

Wu SW, Dal Martello MF, Maloney LT (2009) Sub-optimal allocation of time in sequential movements. PloS one 4:e8228. CrossRef Medline
Zadikoff C, Lang AE (2005) Apraxia in movement disorders. Brain 128: 1480-1497. CrossRef Medline 